\title{
A COMPREHENSIVE INTRODUCTION TO SYNODALITY: RECONFIGURING ECCLESIOLOGY AND ECCLESIAL PRACTICE
}

\begin{abstract}
A bstract. This article contributes to the growing body of literature on synodality with a comprehensive introduction. Firstly, the author observes the link between the synodal approach promoted by Pope Francis and the Second Vatican Council. With the help of Myriam Wijlens' term 'reconfiguration,' he then discusses the theological foundations of a synodal understanding of the Church. Synodality recontextualizes the bishop's responsibility by situating it within the community of the faithful. In addition, as the Holy Spirit is the main actor in the synodal process, all the faithful, including bishops, have to listen to what He is saying, a task that requires discerning the spirits. In the third place, the author focuses on the reconfiguration of ecclesial practice. In a synodal way of proceeding, the traditional virtue of obedience is complemented by various other virtues, such as speaking out, listening with interest, and a deep openness to the Spirit's newness. Finally, the author identifies practical issues that need attention.
\end{abstract}

Keywords: Holy Spirit; listening; participation; people of God; renewal.

The Roman-Catholic Church finds itself in the midst of a synodal process. What was initially designed as primarily a Synod of Bishops on synodality, is now preceded by a synodal process involving all the faithful under the name of "Synod 20212023." The entire Church is on a pilgrimage, eager to hear what the Holy Spirit is saying to the Church

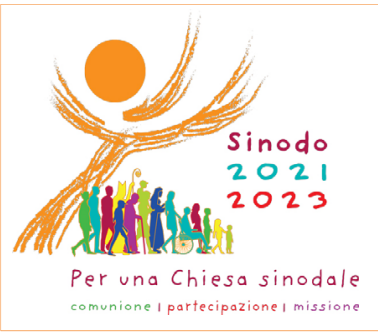

Jos Moons, S.J., PhD - Katholieke Universiteit Leuven, Faculty of Theology and Religious Studies; correspondence address: Sint-Michielsstraat 4, box 3101, 3000 Leuven, Belgium; e-mail: jos.moons@kuleuven.be; ORCID: https://orcid. org/0000-0002-5928-5202.

${ }^{1} \mathrm{Cf}$. the official logo, https://www.synod.va/it/news/synod-official-logo.html (copied above into my text). Originally planned for 2022, the Synod of Bishops was delayed to 2023 in order to allow for a synodal process in which the entire church could participate. In the new format, the Synod of Bishops is to be understood as the concluding part of the entire process. 
at this moment in time. Much more is at stake than the preparation for the 2023 Synod of Bishops. This process is about a new ecclesial lifestyle that should also mark the time after the Synod, and that is characterized by words like conversation, openness, journeying, and the Holy Spirit.

In order to be truly journeying together, with all the faithful participating, it is important that everyone knows more or less what synodality means. Arguably, that is not the case. While many articles and books are available, these often offer specialist reflections on synodality. Important as these may be, they do provide a general presentation of what is going on and to know how to participate. The purpose of this contribution is therefore to provide an introduction of a more general kind at the service of pastors, parishioneers, volunteers, and others, that hopefully serves theologians also.

My reflection consists of four points. Firstly, I discuss the context of the synodal 'fever' of the moment, focusing on its driving force, Pope Francis, and on the Second Vatican Council (1962-1965). Secondly, I present the theological basis of synodality. For while synodality is something new, it is well grounded in the Catholic faith nonetheless. In my third point, I focus on a number of essential spiritual attitudes. Synodality being a practice rather than a theory, it requires a new culture, with new virtues, such as speaking frankly or mutual listening. Finally, in the conclusion I mention some practical issues that affect the synodal process and that therefore need attention, such as training. ${ }^{2}$

\section{POPE FRANCIS AND THE SECOND VATICAN COUNCIL}

From the very start of his pontificate, Pope Francis has been speaking about synodality. In a memorable address at the occasion of the 50th anniversary of the Synod of Bishops, Pope Francis famously stated: "From the beginning of my ministry as Bishop of Rome, I sought to enhance the Synod, which is one of the most precious legacies of the Second Vatican Council."3

\footnotetext{
${ }^{2}$ This article is a significantly elaborated version of an article that was originally written for the Belgian journal Collationes. Vlaams tijdschrift voor Theologie en Pastoraal. The journal gave kind permission for a translation. While writing, I was also working on two other papers, which may contain similar ideas: "Synodality, the Holy Spirit, and Discernment of Spirits," in Synodality in the Everyday Life of the Church, ed. Eamonn Conway and Eugene Duffy (Dublin: Columba Press, in press) and "Synodality and Discernment. The Pneumatological and Affective Reconfiguration of the Church," that is yet to be published.

${ }^{3}$ Address during the Ceremony Commemorating the $50^{\text {th }}$ Anniversary of the Institution of the Synod of Bishops (17 October 2015); the address was held in the context of the Synod
} 
One finds him do so in the new format of interviews, such as the famous 2013 interview by Antonio Spadaro, shortly after his election, that was published in Jesuit journals around the globe, ${ }^{4}$ or the more recent interview by Austen Ivereigh, that was published as a book. ${ }^{5}$ The topic also features in the more classical formats of encyclicals, exhortations, homilies, and so on.

According to the Pope, the option for synodality is not a matter of personal taste, it is what the world expects of the Church and what God calls us to. In his own words: "We must continue along this path. The world in which we live, and which we are called to love and serve, even with its contradictions, demands that the Church strengthen cooperation in all areas of her mission. It is precisely this path of synodality which God expects of the Church of the third millennium." 6

In these texts and elsewhere, Pope Francis presents his commitment to synodality explicitly as a way to follow up on the Second Vatican Council. Interestingly, Vatican II spoke of itself both as a council and a synod, using these terms in fact as synonyms. For example, the Constitution on Sacred Liturgy, Sacrosanctum Concilium (1963), speaks in its opening lines of "this most sacred council." Similarly, the opening lines of the Dogmatic Constitution on the Church, Lumen Gentium (1964), qualify the Council as "this most sacred synod." The official title of the Acts of the Council, that contain all the draft texts and all the interventions of the Council fathers, features both words: Acta synodalia Sacrosancti Concilii Oecumenici Vaticanii II.

More important than this textual detail is the fact that the Council actually worked in a synodal manner. Prior to the Council, in a worldwide consultation, bishops, religious orders and congregations, and Catholic universities were asked for themes that the Council should deal with. Unfortu-

on the Family and is available online at https://www.vatican.va/content/francesco/en/speeches/ 2015/ october/documents/papa-francesco_2015 1017_50-anniversario-sinodo.html. Cf. Massimo Faggioli, "From Collegiality to Synodality: Promise and Limits of Francis's 'Listening Primacy'," Irish Theological Quarterly 85 (2020): 352-369.

${ }^{4}$ Antonio Spadaro, "A Big Heart Open to God: An Interview with Pope Francis," America Magazine. The Jesuit Review of Faith \& Culture (September 30, 2013), https://www.america magazine.org/faith/2013/09/30/big-heart-open-god-interview-pope-francis; also available, e.g., in German (Stimmen der Zeit: die Zeitschrift für christliche Kultur) and in French (Études. Revue de culture contemporaine); also online at vatican.va.

${ }^{5}$ Austen Ivereigh, Let us Dream: The Path to a Better Future. Pope Francis in Conversation with Austen Ivereigh (London: Simon Schuster, 2020).

${ }^{6}$ See the previous note. In the meantime, the International Theological Commission was preparing its document on synodality, "Synodality in the Life of the Church," prepared between 2014 and 2017, and published in March 2018, available: Holy See, accessed 04.01.2022, https:// www.vatican.va/roman_curia/congregations/cfaith/cti_documents/rc_cti_20180302_sino dalita_en.html. 
nately, their input did not play a major role in the preparation of the first drafts; thus, the first opportunity for synodality was (largely) missed. ${ }^{7}$ This changed when some 2.000 bishops gathered in St Peter's for the First Session of the Council. They turned out to have ideas of their own (that were often inspired by their theological advisors). Embracing John XXIII's proposal for a more positive attitude towards modernity and for another, pastoral style, ${ }^{8}$ they cricitized the approach that characterized the prepared drafts. As a result almost all drafts were rejected. ${ }^{9}$

What was at stake went beyond theological content or style; it was about participation. The Council fathers wanted to have a say in the conciliar process, the Council's texts and its direction. What they did not want any more, was nodding their assent to what the Vatican - and more specifically, the Holy Office, which is now the Congregation for the Doctrine of the Faith - tried to softly force on them. In this regard, it was highly significant that on the Council's first working day, 13 October 1962, the Cardinals Achille Liénart and Joseph Frings requested postponing the vote on the members for the various comissions, so that the Council fathers could get to know one another first. This proposal was greeted with ample plausus in aula (applause in the hall) by the Council fathers. Experts considered this the birth of the Council. ${ }^{10}$

The new way of proceeding meant that the Council lasted much longer than initially foreseen (in so far as anything was foreseen, really), namely four years: 1962-1965. Each of these years, the bishops gathered for autumn sessions that lasted roughly two and a half months. On the basis of their observations, commissions made up of bishops and theologians wrote drafts

\footnotetext{
${ }^{7}$ For background and details, see Etienne Fouilloux, "The Antepreparatory Phase: The Slow Emergence from Inertia (January, 1959-October, 1962)," in History of Vatican II, vol. 1, ed. Giuseppe Alberigo and Joseph Komonchak (Leuven: Peeters, 1995), 55-166. The best general introduction to the Second Vatican Council remains John O'Malley, What Happened at Vatican II (Cambridge, MA: Harvard University Press, 2008).

${ }^{8}$ For background and details, see Giuseppe Alberigo, "Le ragione dell'opzione pastorale del Vaticano II," Synaxis 20 (2002): 489-509. During the First Session, the notion of pastorality became more and more influential for determining the Council's orientation, and so did John XXIII's opening address Gaudet Mater Ecclesia, in which the term had been used prominently.

${ }^{9}$ The two exceptions are: the (now outdated) Decree on the Media of Social Communications, Inter Mirifica, and the Constitution on Sacred Liturgy, Sacrosanctum Concilium, both of which were approved in 1963.

${ }^{10}$ For the request, applause and proposal, see the Acts of the Council, Acta synodalia I/1, 207208. For background and details, see Andrea Riccardi, "The Tumultuous Opening Days of the Council," History of Vatican II, vol. 2, ed. Alberigo and Joseph Komonchak (Leuven: Peeters, 1997), 1-67, at 26-32.
} 
which the Council fathers could comment the following year (or later during the same session). Finally, they voted at two levels. First, was this in general what they wanted to say? Second, what details did they want to change? After fine-tuning and one more vote, the texts were published.

After the Council, efforts were made to continue this synodal way of governing, among other things by establishing Synods of Bishops. In 2014 and 2015, for example, the bishops met for the Synod on the Family, which was followed by the much-discussed post-synodal exhortation Amoris Laetitia (2016). Other instruments of governance also breathe a synodal spirit, such as the Conference of Bishops, an institution from before the Council that was confirmed and revived in the Decree on the Pastoral Office of Bishops in the Church, Christus Dominus (1965). The same can be said about various kinds of consultative bodies at the parish level recommended by the Decree on the Apostolate of the Laity, Apostolicam Actuositatem (1965), such as the pastoral council.

However, in the course of the years, two weaknesses have come to the fore. First, the synodal spirit has lost its appeal and power. During Synods of Bishops, there has been less and less actual dialogue. Pope Francis' repeated call for bishops to speak freely and not to be 'their master's voice' is telling: apparently this was unusual. ${ }^{11}$ At the level of Conferences of Bishops, too, the fraternal and dialogical culture which is required for a synodal way of proceeding, is sometimes found lacking, and at the local level it is no different.

A second weakness concerns the participants. Who is involved, and who is not? After the Council, synodality was largely limited to espiscopal collegiality, one of the Council's rediscoveries. The involvement of lay people has remained marginal, which weakens the reliability of outcomes of Synods of Bishops. For example, how is it possible for bishops to consider family

\footnotetext{
${ }^{11}$ Cf. already in the 2013 interview: "Over time I learned many things. The Lord has allowed this growth in knowledge of government through my faults and my sins. So as Archbishop of Buenos Aires, I had a meeting with the six auxiliary bishops every two weeks, and several times a year with the council of priests. They asked questions and we opened the floor for discussion. This greatly helped me to make the best decisions. But now I hear some people tell me: 'Do not consult too much, and decide by yourself.' Instead, I believe that consultation is very important. The consistories [of cardinals], the synods [of bishops] are, for example, important places to make real and active this consultation. We must, however, give them a less rigid form. I do not want token [ = formal, J.M.] consultations, but real consultations. The consultation group of eight cardinals, this 'outsider' advisory group, is not only my decision, but it is the result of the will of the cardinals, as it was expressed in the general congregations before the conclave. And I want to see that this is a real, not ceremonial consultation," Spadaro, "A Big Heart Open to God: An Interview with Pope Francis."
} 
life issues (during the Synod on the Family) without substantial input from the experts, that is, from married lay faithful? Oviously, lay experiences are also important for topics other than the family and at other, more local levels. On both points, Pope Francis has clearly been advocating change.

\section{THE THEOLOGICAL FOUNDATIONS OF SYNODALITY}

Synodality may be something new and involve substantial changes in Church practice and teaching, it has solid theological foundations. To borrow Myriam Wijlens' term, these changes are best understood as a "reconfiguration." The same religious convictions are assembled differently, with priority shifts that result in certain faith convictions becoming more important and others less so. ${ }^{12}$ Therefore, in more polemical terms, synodality is not a lamentable surrender to modern times. Rather, synodality has its roots in the Catholic faith itself. Below I will present these roots and explain what is shifting at the level of faith of convictions, or, if you like, theology. In fact, each of the faith convictions I will discuss presupposes practice and shifts in practice: a different culture, different virtues, a different spirituality. For the sake of clarity, I will take up the practical implications only in the next section.

\section{(1) The Holy Spirit}

In the first place, the synodal approach gives priority to the Holy Spirit. Both the frequency with which Pope Francis speaks about the Spirit in relation to synodality and the form of his pneumatology stand out: he presents the Spirit as an actor with agency. Examples abound. For example, in the interview book with Ivereigh Francis stated: "What characterizes a synodal path is the role of the Holy Spirit. We listen, we discuss in groups, but above all we pay attention to what the Spirit has to say to us."13 Therefore, "we cannot speak of synodality unless we accept and live the presence of the Holy Spirit." ${ }^{14}$ For Pope Francis, this 'presence' must be understood in an

\footnotetext{
${ }^{12}$ Myriam Wijlens, "Reforming the Church by Hitting the Reset Button: Reconfiguring Collegiality within Synodality because of sensus fidei fidelium," The Canonist 8 (2017): 235261. Wijlens is a Professor of Canon Law at the University of Erfurt and one of the theological 'consultors' to the Synod of Bishops and, more largely, the synodal process.

${ }^{13}$ Ivereigh, Let us Dream, 85.

${ }^{14}$ Ibid., 86.
} 
active manner. Looking back on the Synod on the Family, he noted: "Yet the Spirit saved us in the end, in a breakthrough at the close of the second meeting of the Synod on the Family." 15 This goes with openness to new ideas, which he calls "the new things of the Spirit," and it requires listening without "predetermined agendas," for "Ours is a God of Surprises." 16

The importance of the Spirit is also evident in the so-called 'Adsumus' prayer recommended in the official "Guidebook" (Vademecum) for the 2021-2023 process. While Catholic prayers are usually addressed to the Father or the Son, this prayer focuses on the Spirit. Moreover, in this prayer too, the Holy Spirit is imagined as an actor: "We stand before You, Holy Spirit, as we gather together in Your name. With You alone to guide us, make Yourself at home in our hearts. Teach us the way we must go and how we are to pursue it." 17

Texts like these are remarkable for their explicit focus on the Holy Spirit and the active articulation of his role. The Latin Church has an unfortunate tradition of Geistvergessenheit, that is, the tendency to either overlook the Spirit, e.g., by not mentioning the Spirit, or to acknowledge only a secondary role, e.g., as Christ's instrument. ${ }^{18}$ The pneumatological interpretation of God's agency in the Adsumus prayer and in Pope Francis' vision of synodality must therefore be noted and greeted with consolation. Importantly, this does not discard other essential faith convictions, such as God's self-revelation in Christ, or God missioning the apostles and their successors - the bishops - to lead the Church. Rather, these faith convictions are 'reconfigured' by reclaiming other faith conviction that the Church may have forgotten somewhat, and that highlight the Holy Spirit. For example, God has not only spoken in the past, in Christ, yet is still speaking to us

\footnotetext{
${ }^{15}$ Ibid., 88.

${ }^{16}$ Ibid., 93. The word featured also in the 2013 interview "A Big Heart Open to God," in which the Pope is quoted as saying: "... God is always a surprise, so you never know where and how you will find him." Would the Pope be familiar with the British Jesuit Gerard Hughes' bestseller, God of Surprises (London: DLT, 1985), translated into many languages, amongst which Spanish?

${ }^{17}$ Full text available online, see https://www.synod.va/content/dam/synod/document/common/ adsumus/EN-ADSUMUS.pdf. There does not seem to be a Polish translation yet.

${ }^{18}$ For a topical illustration, see the exploration of the Geistvergessenheit in the epicleses in Jos Moons, "The Holy Spirit 'Artisan of the Eucharist'? A Critical Analysis and Evaluation of the Epicleses in the Eucharistic Prayers of the Roman Rite," Horizons. The Journal of the College Theology Society 48 (2021): 69-98. The article includes a discussion of technical Trinitariantheological aspects that one cannot avoid when thematizing the Spirit's agency, such as appropriation and the ad extra rule.
} 
now, through the Holy Spirit. Moreover, God is leading us both by means of the bishops and himself, through the Holy Spirit. In short, synodality renews the Church's faith in the Holy Spirit.

\section{(2) The Church: Together on a Pilgrim Journey}

Secondly, the synodal way of thinking gives more weight to the image of the Church as a pilgrim, understood as the people of God - all the faithful - being on a journey. What the word 'synod' actually means. Both parts of the word should be emphasized. It is a journey together, sun, and is therefore not limited to only the hierarchy; and it is a journey, Gr. óós [odos], so it involves searching, unexpected vistas and encounters, in short: openness. Prioritizing this image of the Church undeniably affects the significance of the Church as a hierarchical organisation and the guardian of the tradition. While not abolishing the truths preserved in the tradition, the synodal reconfiguration implies a modification of their importance; they are not fixed and unchangeable.

The notions 'together' and 'pilgrim' belong to the very essence of the Second Vatican Council's ecclesiology. Lumen Gentium emphasizes that Church means in the first place: the gathering of the faithful. Sharing the baptismal dignity of being vested in Christ and anointed with the Holy Spirit, they make up the Church community. God calls the faithful to communion in confessing the faith and building up the Kingdom. Only after having elaborated what this means - in chapter 2 - does Lumen Gentium go on to discuss the variety of functions and ministries in the Church - in chapters 3 and $4 .{ }^{19}$

Two notions that strongly express this shared dignity deserve to be mentioned: the 'sense of the faith' (sensus fidei fidelium) and the charisms (charismata), both discussed in Lumen Gentium no. 12. The Spirit dwells in every believer, bestowing some sort of a faith intuition. This sensus fidelium is a source of truth and revelation. It is one of the ways in which the Spirit

\footnotetext{
${ }^{19}$ For a more extensive discussion of the structure of the document and its meaning, see the presentation and interpretation by its main editor, Gerard Philips (1899-1972), who was a professor in Leuven, "La Constitution dogmatique sur l'Église Lumen Gentium," Ephemerides Theologicae Lovaniensis 42 (1966): 5-39, at 33. After stating that “[d]ans le plan tel qu'il résulte maintenant des travaux les chapitres marchent deux à deux d'après un enchaînement logique incontenstable," Philips presents the following structure: chapters 1-2 deal with the mystery of the Church, chapters 3-4 focus on the structure of the Church, chapters 5-6 address the Church's direction and orientation (finalité), and chapters 7-8 present the eschatological dimension of the Church. Cf. the Ordinatio totius schematis in the "Relatio adiuncta de problemate ordinationis materiae," which was probably written by Philips, Acta synodalia III/1, 334-335.
} 
speaks to the Church nowadays. Therefore, it is important to listen to everyone. Unfortunately, until quite recently the notion has been largely ignored in magisterial teaching. ${ }^{20}$ However, in light of what is at stake - which is nothing less than the Spirit itself - the sensus fidelium deserves a generous reading that equally stresses the need to purify the sensus fidelium and the need to acknowledge the possibity that God might be trying to speak to us. ${ }^{21}$

More practically too, all the faithful make up the Church. As Lumen Gentium 12 specifies immediately after the sensus fidelium, the Spirit also works in each and every member of the Church with special gifts or charisms, that are meant for building up the Church and, more widely, the Kingdom of God. In the Church and in the Kingdom, all have something to contribute, no one is only a recipient. ${ }^{22}$

In addition to 'together,' synodality also imagines the Church as being on a journey. It implies a dynamic and open understanding of the Church: we are searching our way. This notion echoes the modern meaning of eschatology as concerning mankind's ultimate destination, God, rather than heaven and hell, and which has left its mark on Lumen Gentium's chapter on "The Eschatological Character of the Pilgrim Church and Its Unity with the Heavenly Church." 23 As Yves Congar noted when he looked back on the

${ }^{20}$ Two highlights in the magisterial recovery of sensus fidelium are the International Theological Commission's document "Sensus Fidei in the Life of the Church" (2014) and, more generally (and more properly magisterial), the papacy of Pope Francis. For the extensive interest amongst scholars, cf. the material gathered in the overview articles by John J. Burkhard: "Sensus Fidei: Theological Reflection Since Vatican II. Part I: 1965-1984," The Heythrop Journal 34 (1993): 41-59, "Sensus Fidei: Theological Reflection Since Vatican II. Part II: 1985-1989," in The Heythrop Journal 34 (1993): 123-136, "Sensus Fidei: Recent Theological Reflection (19902001). Part I," The Heythrop Journal 46 (2005): 450-475, and "Sensus Fidei: Recent Theological Reflection (1990-2001). Part II," The Heythrop Journal 47 (2006): 38-54.

${ }^{21}$ For a comprehensive constructive reflection, see Ormond Rush's wonderul reflection, The Eyes of the Faith. The Sense of the Faithful and the Church's Reception of Revelation (Washington: Catholic University of America Press, 2009). Cf. Jos Moons, "“Aroused and sustained by the Holy Spirit'? A Plea for a Pneumatological Reconsideration of Sensus Fidei on the Basis of Lumen Gentium 12," Gregorianum 99 (2018): 271-292.

${ }^{22}$ The notion of charisms is not yet mature and needs further theological elaboration, see Jos Moons, "The Holy Spirit Leads the Church through Charismas' (LG 12). The Conciliar Doctrine on Charismas and its Significance for the Laity's Active Involvement in the Church," in The Letter and the Spirit: On the Forgotten Documents of Vatican II, ed. Annemarie Mayer (Leuven: Peeters, 2018), 233-245.

${ }^{23}$ What was originally a chapter on the veneration of the saints, was reframed in the context of the Church's journey from God and towards God. For a sketch of the redaction process including the relevant sources, see Jos Moons, The Holy Spirit, the Church, and Pneumatological Renewal. Mystici Corporis, Lumen Gentium and Beyond (Leiden / Boston: Brill, 2022), 271-286. 
discussion on this point during the Council: "Eschatology means: what concerns the ultimate realities. Yet, here the aim was not to discuss the nature of the 'things' one encounters at the end: judgement, heaven, hell, purgatory. It was not about that, but rather about the dimension and character that the Church has because of its state of pilgrim." 24 As a result, Lumen Gentium is characterized by an inclusio: just like the first two chapters explore the Church's origin from God, the last two chapters recall God as the Church's final destination. ${ }^{25}$

More concretely, in light of the Church's pilgrim nature, synodality radically reconceives the distinction between the hierarchy as ecclesia docens (the Church that teaches) and the laity as ecclesia discens (the Church that learns): ultimately the Church is always primarily learning. Moreover, in so far as one is a good student, everyone may be teaching. The Magisterium's Teaching Office is not abolished but should be situated in the context of these latter convictions.

\section{(3) The Discernment of Spirits}

A major problem in the pilgrim Church of the synodal type is the multiplicity of voices, that may well be opposed. How to choose from these voices? How should the Church know which voices reflect the gospel more, and which ones less? Or, in terms of the Spirit, how do we know in which voices the Holy Spirit is speaking to the Church and in which voices it does not? In a synodal context, the traditional answer that 'that is for the Magisterium to decide', is premature, for it excludes the lay faithful from the process of finding truth. The question, therefore, is how to sift and purify the available material so that God may speak through the variety of voice. After the chaff has been blown away, the wheat can be welcomed joyfully. The tool for that purifying process is the discernment of spirits. In presentations

${ }^{24}$ Cf. The French text, "Eschatologie ... signifie: ce qui concerne les réalités dernières. Cependant, il ne s'agissait pas de traiter ici de la nature des 'choses' qu' on trouve à la fin: Jugement, Ciel, Enfer, Purgatoire.... Ce n'est pas de cela qu'il était question, mais bien de la dimension et du caractère que prend l'Église, en son état d'itinérance...," Yves Congar, Le Concile au jour le jour. Troisième Session (Paris: Les Éditions du Cerf, 1965), 30-31.

${ }^{25}$ Cf. Philips' comment on the Marian chapter: "La finale décrit Marie comme signe de consolation pour le peuple de Dieu en pèlerinage sur la terre et exprime un espoir de concorde en l'honneur de la Sainte Trinité. Ainsi la Constitution Lumen Gentium commence et finit par le mystère fondamental de Trois Personnes," Philips, "La Constitution dogmatique sur l'Église Lumen Gentium," 36. 
on synodality, the word is often used but rarely explained, which is what I will do succintly.

The discernment of spirits is a spiritual method for finding truth and wisdom. Over time, it has been understood in quite different ways, as the fascinating overview by American Jesuit scholar Joseph T. Lienhart shows. ${ }^{26}$ For early Greek Scripture commentators like Chrysostom (347-407), the discernment mentioned in 1 Corinthians 12 was about distinguishing the spiritual person from soothsayers and false prophets. In early Latin commentaries on that text, however, discernment is understood in relation to distinguishing, not between persons, but between the inspirations or 'spirits' that accompany someone's actions or words. Later this is being 'de-spiritized' into virtues, especially in the virtue of moderation celebrated in the Benedictine tradition, and that belongs especially to the abbot. ${ }^{27}$

In its Ignatian understanding, discernment is based on interiority and affectivity. ${ }^{28}$ It presupposes a 'good spirit' (that is often identified with the Holy Spirit) and a 'bad spirit' (that is often identified with the devil), who cause inner 'movements' such as peace, unrest, joy, earthly desires, mild-

${ }^{26}$ Joseph T. Lienhart, “On 'Discernment of Spirits' in the Early Church,” Theological Studies 41 (1980): 505-552, including other sources, such as the extensive lemmas on 'discernement des esprits' and 'discretion' in the Dictionaire de spiritualité, vol. III (Paris: Beauchesne, 1957), 1222-1291 and 1311-1330. Cf. Santiago G. Arzubialde, "Discretio," in Diccionario de Espiritualidad Ignaciana, ed. José García de Castro and others (Bilbao/Santander: Mensajero, 2007), 623-637.

${ }^{27}$ See Lienhart, "On 'Discernment of Spirits' in the Early Church," 526-528. For the link between discernment and moderation, see chapter LXVI of the Rule, verses 17-19: "[H]e must show forethought and consideration in his orders, and whether the task he assigns concerns God or the world, he should be discerning and moderate [discernat et temperet], bearing in mind the discretion of holy Jacob, who said: 'If I drive my flocks too hard, they will all die in a single day' (Gen 33:13). Therefore, drawing on this and other examples of descretion [discretionis], the mother of virtues, he must so arrange everything that the strong have something to yearn for and the weak nothing to run from," The Rule of St. Benedict. In Latin and English with Notes, ed. Timothy Fry and others (Collegeville, MN: The Liturgical Press, 1980), cf. chapters II (Qualis debeat esse abbas) and LXIV (De ordinando abbate).

${ }^{28}$ The so-called 'Rules for Discernment' in the Spiritual Exercises, no. 313-336, present in highly condensed form the Ignatian wisdom on discernment, see for example: Personal Writings. Reminiscences, Spiritual Diary, Select Letters, Including the Text of the Spiritual Exercises, tr. and intr. Joseph A. Munitiz and Philip Endean (London: Penguin Books, 1996). The standard commentary on these rules is still Jules J. Toner, A Commentary on Saint Ignatius' Rules for the Discernment of Spirits. A Guide to the Principles and Practice (Saint Louis: The Institute of Jesuit Sources, 1982). For a more developed and applied, more recent commentary, see Timothy M. Gallagher, The Discernment of Spirits. An Ignatian Guide for Everyday Living (New York: Crossroad Publishing Company, 2005), and Spiritual Consolation. An Ignatian Guide for the Greater Discernment of Spirits (New York: Crossroad Publishing Company, 2007). 
ness, bitterness, and so on. Discernment is the art of interpreting these movements: which ones indicate that God is trying to communicate something to us and which ones do not? Which ones should we reverently welcome, and which ones not?

Discernment presupposes great inner freedom or, in jargon, 'indifference'. One can only discern on the basis of a profound openness that is bound neither by my own preferences or convictions, nor by what 'people' say, what I think Church teaching is saying, or even my own feelings. Instead, it gives space to a variety of views, opinions, experiences. Once this has opened up space, so that God can actually speak to me, two questions must be asked. Firstly, what is the 'aftertaste' of a given view, opinion, experience? Is there depth, peace, love, wisdom, ...? Or rather, does it give a blunt, sharp, or cynical sensation? The first is in most cases an indication of God's presence; the second typically is not. A second question explores the fruits of a given plan or option. Does it lead towards the Kingdom, towards God, towards greater service of fellow human beings? Or should one humbly admit that a given plan or option serves one's own interests and 'kingdom' more than God or neighbour? In the latter case, one is better off leaving it.

With the greater prominence of discernment of spirits, the Church finds herself once again in the midst of a reconfiguration. For discernment is part and parcel of the Roman Catholic tradition. It characterizes certain religious families, such as the Ignatian one, to which the Jesuits belong, and is used in specific settings, especially to discern a religious vocation. Yet synodality increases its status: from an option for certain groups or situations, it becomes a task for each and everyone.

By way of conclusion, let me make two short comments. First, it is obvious that this process presupposes a certain 'life style' that is in tune with God's 'wavelength'; this considerably facilitates one's sensing of God. This includes prayer, familiarity with the gospel, service of neighbour, involvement in the Church. In the second place, it is obvious too that discernment can go wrong. In identifying God's presence, one may err, or rather, one will err. Still, that is not unique for discernment; other methods of truth finding can go wrong too. As the pharisees in Scripture painfully demonstrate, this may include seemingly pious devotion to the law. 


\section{(4) The Bishops}

The fourth pillar of synodality is the bishop, or rather in plural: are the bishops. In a synodal view of the Church, bishops continue to fulfil an important role. Anointed by the Spirit, missioned by Christ, and appointed by the Pope, they are to shepherd their flock, in collegial union with their fellow bishops. As such, bishops have the final word in a synodal process too. Yet once more, that responsibility is reconfigured. The major shift here is, firstly, that they have the final word; prior to that, they should listen. Moreover, and secondly, the episcopal responsibility includes organizing the process of consultation, dialogue, and conversation. They should be facilitating their own listening and learning process.

\section{SYNODALITY AS A PRACTICE: ANOTHER ECCLESIAL CULTURE}

The reconfigurations discussed so far were mainly theoretical. They dealt with changes in the way faith is articulated in words and concepts; they were theological reconfigurations. Yet, as I already indicated, that is only half the story. As synodality is primarily a practice, a way of being Church, what practical reconfigurations doet it involve? That is not merely a theoretical question. While we are still at the early stages of the adventure of synodality, it is already very visible that synodality involves new attitudes, practices and virtues indeed - in short, another ecclesial culture. For example, the traditional virtue of obedience is now complemented with the virtue of honestly sharing one's views. Without the latter, synodality cannot be. So what is the reconfigured ecclesial culture that synodality presupposes? In what follows I will highlight five characteristics.

\section{(1) Openness and Unclarity}

In the first place, a synodal ecclesial culture is characterized by openness. Traditionally, ecclesial culture celebrates the virtue of loyalty to what has been handed on, or in more simple terms, the old and familiar. Synodality promotes also the opposite as being a virtue. Or in terms of reconfiguration: the virtue of being loyal to tradition is now complemented with being open to newness. The theological underpinning of this openess is the conviction 
that it is ultimately the Spirit who leads the Church, and that the Church must give the Spirit its space. The spiritual tradition of discernment, calls this type of openness "indifference," an inner freedom of being attached to nothing but God.

Openness is easier said than done. It means that one should be ready to listen to other views and voices than one is used to. Yet in general human nature typically avoids what is different. Moreover, openess comes with bearing unclarity. As long as the conversation lasts things are not clear, something that often feels strange or even bad. Generally speaking, human nature prefers certainty and clarity, a preference that in ecclesial contexts is sometimes reinforced by appealing to 'orthodoxy' as an extra defense wall. In a synodal way of proceeding, a lack of clarity is unavoidable. As a step or a phase in the process of purifying the diversity voices, it is even essential.

In a short reflection on the Church's relationship with modernity, the American ecclesiologist Paul Lakeland used the lovely word "the grace of selfd-doubt." 29 The word grace helps to articulate theologically what openness and bearing unclarity are about: detachment of oneself in order to encounter God - which may involve surprise.

\section{(2) Speaking Out}

In the second place, a synodal ecclesial culture is characterized by frankness. It considers speaking out a virtue, not a vice. A cynical joke describes the laity's role in the pre-Vatican II Church as 'to pay, to pray and to obey'. There's more than a grain of truth in this joke, and part of that truth is still relevant, as ecclesial culture usually promotes not speaking out. For a synodal way of proceeding, however, participation and dialogue are essential, and therefore, speaking out.

The objective of speaking out is not simply to vent one's feelings or thoughts now that at last bishops are willing to listen. Speaking one's mind (or indeed, one's heart) should be a way of contributing to the listening exercise. It requires a peculiar combination of humility and boldness. One should abstain from modelling one's contribution on others and simply share what one believes to be the Spirit's inspiration, neither echoing (or contradicting) the pope, the bishop, or one's best friend. No matter what people

\footnotetext{
${ }^{29}$ Paul Lakeland, "Reflections on the 'Grace of Self-Doubt'," in Ecclesiology and Exclusion. Boundaries of Being and Belonging in Postmodern Times, ed. Dennis M. Doyle, Timothy J. Furry, and Pascal D. Bazzell (Maryknoll, NY: Orbis 2012), 13-17.
} 
may think about it, this one shares, thus speaking with the 'liberty of the children of God' in view of the greater good of the Church.

Obviously, the chance that one effectively contributes to the Church's greater good increases significantly by thinking before speaking, by familiarity with Scripture, by conversation with other persons, by a life of Christian service, and so on. Moreover, it becomes significantly more possible that one's word may be recognized as 'from the Spirit' if care has been taken to articulate it well: calmly, clearly and understandably, without agression, bitterness, or any other type of violence.

To embrace speaking out as a virtue is yet another synodal reconfiguration. It broadens the range of the ways in which Catholics can participate in ecclesial conversation. Ecclesial conversation should be reimagined as being not about 'yes, I agree,' or 'no, I don't agree,' but about sharing perspectives and views in search for what comes closest to God's word for the Church at this moment in time.

Introducing, developing, and promoting this new virtue is a weighty task for all Church members. Bishops have to give space to the laity to speak. Beyond bearing diversity and unclarity, it means reconceiving episcopal ministry in such a way that it includes welcoming the laity's contribution. Since Vatican II, the bishop's 'alter Christus' (another Christ) identity means also that they should welcome Christ's presence in the faithful. ${ }^{30}$ The laity too have an important responsibility. Overcoming preconciliar pasivity, they should boldly speak out in a constructive manner. Arguably, this implies reconceiving the virtue of humility. Finally, all should familiarize themselves with the art of gracefully communicating their views.

\section{(3) Listening with Interest}

Further, a synodal ecclesial culture is characterized by the virtue of listening with interest. The qualification 'with interest' serves to distinguish this type of listening from the type of listening that one encounters in discussions or arguments. Instead of responding 'yes, but..., an interested listener wishes the other person to say more and explores what the other person

\footnotetext{
${ }^{30}$ The fact that the laity share in the common priesthood (cf. Lumen gentium 10), requires for a new reflection on hierarchical ministry, cf. Jos Moons, "Welcoming Christ in the Faithful. Theology and Spirituality of Ministry in Light of Vatican II" [published in Dutch as "Christus begroeten in de gelovigen. Theologie en spiritualiteit van het ambt in het licht van Vaticanum II'], in Spiritualiteit - Ambt - Roeping. Theologische verkenningen, ed. Peter-Ben Smit (Sliedrecht: Merweboek, 2018), 11-21.
} 
means. Ideally, this develops into a conversation in which all involved share their views in an atmosphere of mutual listening. While that exchange of views is happening, people should constanty attempt to sense what wisdom or truth is being articulated or evoked, for the conversation's ultimate goal is to discover the Spirit. Usually, his presence is felt better by means of soft-spoken sharing than tough arguments.

Once again, the reconfiguration is clear. Obviously, listening with interest has always been part of Church life. It is part and parcel of spiritual accompaniment and indeed of any type of pastoral conversation. Yet synodality promotes listening with interest to a skill for all to practice and to a feature that should characterize ecclesial culture in general.

The three features discussed so far-openness, speaking out, and listening with interest - are fundamentally related. Openness creates space for the Holy Spirit, as does listening with interest also, yet at a more concrete level. Speaking out fills the space that these two virtues create and thus provides the content that needs to be discerned. Finally, the Holy Spirit is at all times the ultimate concern of the undertaking.

Finally, a long quotation from Pope Francis' homily at the occasion of the opening of the synodal path may support my presentation of virtues so far, for it features the very same points. "Let us ask ourselves frankly during this synodal process: Are we good at listening? How good is the 'hearing' of our heart? Do we allow people to express themselves, to walk in faith even though they have had difficulties in life, and to be part of the life of the community without being hindered, rejected or judged? Participating in a Synod means placing ourselves on the same path as the Word made flesh. It means following in his footsteps, listening to his word along with the words of others. It means discovering with amazement that the Holy Spirit always surprises us, to suggest fresh paths and new ways of speaking. It is a slow and perhaps tiring exercise, this learning to listen to one anotherbishops, priests, religious and laity, all the baptized - and to avoid artificial and shallow and pre-packaged responses. The Spirit asks us to listen to the questions, concerns and hopes of every Church, people and nation. And to listen to the world, to the challenges and changes that it sets before us. Let us not soundproof our hearts; let us not remain barricaded in our certainties. So often our certainties can make us closed. Let us listen to one another." ${ }^{\prime 1}$

\footnotetext{
${ }^{31}$ Homily at the Occasion of the Opening of the Synodal Path (10 October 2021), Holy See, accesed 04.01.2021, https://www.vatican.va/content/francesco/en/homilies/2021/documents/ 20211010 -omelia-sinodo-vescovi.html.
} 


\section{(4) Being in Touch With Interiority}

My presentation of the practise of synodality until now has in fact highlighted what is needed for any true conversation. In doing so, I have left aside two characteristics that distinguish synodal conversations from other types of conversation, namely: the interest in interiority and the submission to the bishop's final word. To start with the former: as I stated above, a synodal type of conversation is not about arguments or discussions, but about a gentle sharing in search of what seems most in accord with the Spirit. While arguments obviously still matter, they are evaluated not only theologically but also, and with a certain priority, with the help of discernment of spirits. Do they radiate peace, wisdom, depth, Gospel, ..., or not? Or again, what is their direction: peace, wisdom, depth, Gospel, ..., or not? In more technical language, the search for the Spirit is a deeply affective spiritual process of discernment of spirits that navigates primarily with the compass of 'inner movements'.

Therefore, synodality presuposes that participants are aware of and in touch with what is going on within. They should speak only when the sense that what they are thinking is at the wavelength of the Spirit. While listening, one should not look for counter arguments, but sense what truth is being communicated. Finally, those who decide, should be guided not by their own convictions (or indeed anybody else's) but by their sense that in a given position the wisdom of the Spirit is resounding best.

Once more, this is a major reconfiguration. Church culture usually focuses on content, viz., correct formulations and truthful convictions, rather than the soul. To a lesser extent, charity matters as well. Synodality draws attention to another crucial dimension of the faith life: the spiritual dimension, which complements orthodoxy and orthopraxis. In a synodal Church, being in touch with one's soul is a key virtue.

\section{(5) Obedience}

Finally, a synodal process cannot take place without the participants accepting a decision once it has been taken. Here too, a certain 'grace' in communicating that decision matters. It certainly makes it easier to accept a decision as something from the Spirit. Moreover, a bishop should be transparant about his reasons. How has he weighed the various possible conclusions? 
Thus, in a synodal Church the classical virtue of obedience, including the submission that goes with it, does not disappear. Yet it is not an absolute and exclusive virtue. Rather, obedience complements the virtue of frankness which itself complements just as much the virtue of obedience. A synodal culture allows space both for conversation and exchange without taboos, and for a final word that paricpants need to obey. A synodal process cannot exist without participants accepting a final decision.

\section{CONCLUSION}

Synodality is a demanding, unsure adventure. The Church is moving from one way of thinking about faith and Church to another, swapping one way of ecclesial practice for another. While we are at it, the destination remains somewhat unclear, except that it will certainly involve tensions. A synodal theology and practice embrace an 'and-and' approach, highlighting Christ and the Spirit, all the faithful and the bishop, speaking and listening, participation and hierarchical ministry, tradition and renewal, and so on. A synodal Church is a Church of constructive tensions. ${ }^{32}$

The synodal 'move' is easier said than done. Things that are straighforward on paper, are not so in reality. A range of practical issues affect (or even determine) the success of the synodal undertaking. For example, synodality requires formation. Who is going to train bishops, priests, deacons, faithful in the new virtues? How to overcome the resistance that usually accompanies change? How to foster a willingness to learn?

In addition, synodality is not the only issue on the table of the Church. The abuse crisis deeply affects the Church in Europe; Poland is no exception in this regard. Clergy and laity alike are trying to come to terms with the victim's intense suffering, the shameful denial by Church leaders, the misguided efforts to blame homosexuality or the sexual revolution, and so on. Secularisation represents another, much slower, long-term challenge, that in fact involves various challenges: re-thinking Christianity in a secular age (as do, for example, Charles Taylor and Tomáš Halík), re-organizing parish

\footnotetext{
${ }^{32}$ On the way tensions may be part of Christian spirituality, see the wonderful book by William A. Barry and Robert G. Doherty, Contemplatives in Action: The Jesuit Way (New York: Paulist Press, 2002). The authors explore various tensions that belong to the essence of a Jesuit lifestyle, such as the tensions between prayer and action, poverty and using resources, or celibacy and friendship.
} 
structures, closing Church buildings, forming laity, and last but not least, reevangelization. On top of that, some difficulties have always existed and will always exist. Bishops invariably have to deal with complaint letters from concerned parishioners. They always have trouble with priests who drink too much, lack pastoral skills, are too liberal (or too conservative), or lead a double life. Financial issues are never absent, and so on. These various crises take up much energy. Is synodality one challenge too much?

For many reasons, therefore, synodality is easier in theory - in theology - than in its practice. Synodality requires conversion: a 'metanoia' that gives up petty, human thinking and opens up to God's perspective. At our best, synodality will take shape gradually. Bishops, priests, and faithful need time to get used to a synodal culture. Maybe synodality should start at a local level, in parish councils and youth groups?

While the adventure is unsure and demanding, I think synodality is important. Much is at stake. The question is if we believe (or not) in the people of God and its pilgrim journey, in the wisdom of discerning the spirits, in the bishop as a shepherd with a double responsability (of facilitating participation and having the final say). Ultimately, synodality is about believing (or not) in the Holy Spirit's 'real presence' and action in the faithful. It may therefore be appropriate to end this presentation with this wish: May we stand before Him. May we gather together in His name. May $\mathrm{He}$ be our guide. May He be at home in our hearts. May He teach us the way we must go and how we are to pursue it, and may we be open to receive whatever He wishes to teach us. ${ }^{33}$

\section{REFERENCES}

Acta synodalia Sacrosancti Concilii Vaticani II. [Vatican City]: Typis polyglottis Vaticanis, 1970-2000.

Alberigo, Giuseppe. "Le ragione dell'opzione pastorale del Vaticano II.” Synaxis 20 (2002): 489509.

Arzubialde, Santiago G. "Discretio." In Diccionario de Espiritualidad Ignaciana, edited by José García de Castro and others, 623-637. Bilbao/Santander: Mensajero, 2007.

Barry, William A., \& Robert G. Doherty. Contemplatives in Action: The Jesuit Way. New York: Paulist Press, 2002.

Benedict of Nursia. The Rule of St. Benedict. In Latin and English with Notes, edited by Timothy Fry, and others. Collegeville, MN: The Liturgical Press, 1980.

\footnotetext{
${ }^{33}$ Adopted from the Adsumus prayer, see footnote 17.
} 
Burkhard, John J. "Sensus Fidei: Theological Reflection Since Vatican II. Part I: 1965-1984." The Heythrop Journal 34 (1993): 41-59.

Burkhard, John J. "Sensus Fidei: Theological Reflection Since Vatican II. Part II: 1985-1989." The Heythrop Journal 34 (1993): 123-136.

Burkhard, John J. "Sensus Fidei: Recent Theological Reflection (1990-2001). Part I." The Heythrop Journal 46 (2005): 450-475.

Burkhard, John J. "Sensus Fidei: Recent Theological Reflection (1990-2001). Part II." The Heythrop Journal 47 (2006): 38-54.

Congar, Yves. Le Concile au jour le jour. Troisième Session. Paris: Les Éditions du Cerf, 1965.

Faggioli, Massimo. "From Collegiality to Synodality: Promise and Limits of Francis's 'Listening Primacy'." Irish Theological Quarterly 85 (2020): 352-369.

Fouilloux, Étienne. "The Antepreparatory Phase: The Slow Emergence from Inertia (January, 1959 - October, 1962)." In History of Vatican II, vol. 1, edited by Giuseppe Alberigo and Joseph Komonchak, 55-166. Leuven: Peeters, 1995.

Francis (Pope). Address during the Ceremony Commemorating the $50^{\text {th }}$ Anniversary of the Institution of the Synod of Bishops (17 October 2015). Holy See. Accessed 04.01.2022. https://www.vatican.va/content/francesco/en/speeches/2015/october/documents/papa-francesco _20151017_50-anniversario-sinodo.html.

Francis (Pope). Homily of His Holiness Pope Francis at the Occasion of the Opening of the Synodal Path (10 October 2021). Holy See. Accessed 04.01.2022. https://www.vatican.va/ content/ francesco/en/homilies/2021/documents/20211010-omelia-sinodo-vescovi.html.

Gallagher, Timothy M. The Discernment of Spirits. An Ignatian Guide for Everyday Living. New York: Crossroad Publishing Company, 2005.

Gallagher, Timothy M. Spiritual Consolation. An Ignatian Guide for the Greater Discernment of Spirits. New York: Crossroad Publishing Company, 2007.

Ignatius Loyola. "Rules for Discernment." In The Spiritual Exercises, no. 313-336.

International Theological Commission. "Sensus Fidei in the Life of the Church," 2014. Holy See. Accessed 04.01.2022. https://www.vatican.va/roman_curia/congregations/cfaith/cti_documents/ rc_cti_20140610_sensus-fidei_en.html.

International Theological Commission. "Synodality in the Life of the Church," 2018. Holy See. Accessed 04.01.2022. https://www.vatican.va/roman_curia/congregations/cfaith/cti_ documents/rc_cti_20180302_sino dalita_en.html.

Ivereigh, Austen. Let us Dream: The Path to a Better Future. Pope Francis in Conversation with Austen Ivereigh. London: Simon Schuster, 2020.

Lakeland, Paul. "Reflections on the 'Grace of Self-Doubt'." In Ecclesiology and Exclusion. Boundaries of Being and Belonging in Postmodern Times, edited by Dennis M. Doyle, Timothy J. Furry, and Pascal D. Bazzell, 13-17. Maryknoll, NY: Orbis, 2012.

Lienhart, Joseph T. "On 'Discernment of Spirits' in the Early Church.” Theological Studies 41 (1980): 505-552.

Moons, Jos. "«Aroused and sustained by the Holy Spirit»? A Plea for a Pneumatological Reconsideration of Sensus Fidei on the Basis of Lumen Gentium 12." Gregorianum 99 (2018): 271-292.

Moons, Jos. "The Holy Spirit 'Artisan of the Eucharist'? A Critical Analysis and Evaluation of the Epicleses in the Eucharistic Prayers of the Roman Rite." Horizons. The Journal of the College Theology Society 48 (2021): 69-98. 
Moons, Jos. "«The Holy Spirit Leads the Church through Charismas» (LG 12). The Conciliar Doctrine on Charismas and its Significance for the Laity's Active Involvement in the Church." In The Letter and the Spirit: On the Forgotten Documents of Vatican II, edited by Annemarie Mayer, 233-245. Leuven: Peeters, 2018.

Moons, Jos. The Holy Spirit, the Church, and Pneumatological Renewal. Mystici Corporis, Lumen Gentium and Beyond. Leiden / Boston: Brill, 2022.

Moons, Jos. "Welcoming Christ in the Faithful. Theology and Spirituality of Ministry in Light of Vatican II," published in Dutch as "Christus begroeten in de gelovigen. Theologie en spiritualiteit van het ambt in het licht van Vaticanum II." In Spiritualiteit - Ambt-Roeping. Theologische verkenningen, edited by Peter-Ben Smit, 11-21. Sliedrecht: Merweboek, 2018.

O'Malley, John. What Happened at Vatican II. Cambridge, MA: Harvard University Press, 2008.

Philips, Gerard. "La Constitution dogmatique sur l'Église Lumen Gentium.” Ephemerides Theologicae Lovaniensis 42 (1966): 5-39.

Riccardi, Andrea. "The Tumultuous Opening Days of the Council." In History of Vatican II, vol. 2, edited by Giuseppe Alberigo and Joseph Komonchak, 1-67. Leuven: Peeters, 1997.

Rush, Ormond. The Eyes of the Faith. The Sense of the Faithful and the Church's Reception of Revelation. Washington: Catholic University of America Press, 2009.

Spadaro, Antonio. "A Big Heart Open to God: An Interview with Pope Francis.” America Magazine. The Jesuit Review of Faith \& Culture. September 30, 2013.

Toner, Jules J. A Commentary on Saint Ignatius' Rules for the Discernment of Spirits. A Guide to the Principles and Practice. Saint Louis: The Institute of Jesuit Sources, 1982.

Wijlens, Myriam. "Reforming the Church by Hitting the Reset Button: Reconfiguring Collegiality within Synodality because of sensus fidei fidelium." The Canonist 8 (2017): 235-261.

\section{KOMPLEKSOWE WPROWADZENIE DO SYNODALNOŚCI: REKONFIGURACJA EKLEZJOLOGII I PRAKTYKI KOŚCIELNEJ}

Streszczenie

Artykuł wzbogaca rosnąca literaturę przedmiotu na temat synodalności poprzez kompleksowe do niej wprowadzenie. Po pierwsze, autor zwraca uwagę na związek między synodalnym podejściem promowanym przez papieża Franciszka i Sobór Watykański II. Za pomocą terminu „rekonfiguracja," wypracowanego przez Myriam Wijlens, autor omawia teologiczne podstawy synodalnego rozumienia Kościoła. Synodalność bowiem rekontekstualizuje odpowiedzialność biskupa, umieszczając ją we wspólnocie wiernych. Jako że Duch Święty jest głównym aktorem procesu synodalnego, wszyscy wierni, w tym także biskupi, muszą słuchać tego, co mówi On. To zadanie wymaga umiejętności rozeznawania duchów. Po trzecie, autor skupia się na rekonfiguracji praktyki kościelnej. W postępowaniu synodalnym tradycyjna cnota posłuszeństwa jest uzupełniana przez różne inne umiejętności, takie jak możliwość wypowiadania się, słuchanie z zainteresowaniem i głębokie otwarcie na nowość Ducha. Na końcu artykułu autor identyfikuje praktyczne kwestie, które wymagają uwagi.

Słowa kluczowe: Duch Święty; słuchający; udział; lud Boży; odnowa. 